\title{
Información sobre el estado de la parroquia de Cobija, por don Juan de la Peña Salazar A.G.I. Charcas Legajo 24, año 1684, 2 fs.
}

Transcripción de Jorge Hidalgo y Rebeca Correa

\section{[f. 1r]}

Doy quenta a vuestra magestad como parese preciso instruir al arzobispo que vbiere de ser de esta sancta yglesia de la ciudad de La Plata del quydado que debe tener con la administrazion de los sanctos sacramentos a los yndios del puerto de Cobixa y los motibos tan necessarios y urgentes que me obligan.

Doy quenta a vuestra magestad como auiendo desembarcado en el puerto de Cobixa quando pasé del reyno de Chile a esta plaza tuue notizi[roto] que los yndios que alli asisten se hallado [sic] con el desconsuelo de faltarles el aliuio que necesitan no solo para la educacion christiana sino tambien para la saluasion porque la omision de el cura en assitirlos es de calidad que me informaron un clerigo que all[roto] estaba abría veinte dias o treinta llamado don Jorge de la Barra y el theniente d[roto] corregidor llamado Lorenco de Almad[roto] que quando llego el dicho don Jorge de 1[roto] Barra de orden de el cura propieta[roto] abia tres años y siete meses que no abian vi[roto] sacerdote alguno y que les abian faltad[roto] los sacramentos a todos los yndios que se abian muerto en aquel tiempo tambien teng[roto] entendido que los visitadores eclesiastico xamas an llegado al dicho puerto de Cob[roto] y asi mismo que no ai memoria de que [roto] llegado a dicho puerto arçobispo algún [roto] //

\section{[f. 1v]}

a hazer confirmasiones y como e visto que dichos yndios se conserban en dicho puerto con grande miseria y desdicha porque no tienen modo de salir de el ni disposicion alguna respecto de que por la esterilidad grande no produze aquella tierra en muchas leguas genero alguno para el sustento y bestuario y que solo se mantienen del pezcado del mar de que ai abundansia y que no tienen leña alguna para haser fuego ni agua que poder veuer mas que la que esta distilando gota a gota de una peña siendo esta agua mui salobre y que los dichos yndios no tienen otro sustento mas que el referido y que para la pesca andan en unas baldas que hasen del pellejo del lobo marino y que de este exersisio continuo de dia y de noche segun lo requiere el tiempo estan ymposibilitados de poder andar a pie ni a cauallo por lo menos distansia considerable y que por esta rrazon supe que xamas salian de aquellos paraxes siendo como es sierto que para la conduccion de los pasageros es preciso bengan indios de Atacama con mulas y lo necesario que es distansia de çinquenta leguas y auiendo rreconosido esto y sabido no ai memoria de que algun arcobispo aiga pasado a dicho puerto se ve bien claro el grande numero que a muerto sin el santo sacramento de la confirmasion y asi mismo no llegando a dicho puerto los visitadores eclesiasticos no es posible que los pobres yndios puedan represen- //

\section{[f. 2 r]}

tar las quejas de sus curas que estos de [ilegible] dinario asisten en Atacama la Baja en un pueblo llamado Chiu Chiu que dista de los lipes çinquenta leguas que es el paraxe a don [roto] de estoi informado los dichos vichadores [roto] que llegen al dicho de Chiu Chiu alguno se queda em pie el yncombeniente supues[roto] que los yndios de Cobixa ni salen ni pue[roto] salir de dicho puerto ame parecido $\mathrm{d}$ [roto] esta quenta a vuestra magestad para el rremed[roto] con la instruccion y advertencia que a [roto] magestad fuere seruiçio al prelado que vbi[roto] de ser de esta santa yglessia pues es bien ne[roto] que aunque el dicho puerto de Cobixa d[roto]ta de esta ciudad ciento y çinquenta leg[roto] poco mas o menos y que las cjnquenta desde Atacama son penosas por la esterilidad grande de la tierra sin agua y sin mantenimient[roto] se puede llebar comodamente lo necesar[roto] y que cabe todo en el partido de tener po[roto] esposa a esta santa yglesia cuias rentas son las de la mayor importancia que ai en yglesia alguna de las yndias y aunque por el rrespeto rreligioso con que vener[roto] las acciones de los prelados no atribuio [roto] referido mas que a otras ocupaciones y fa[1]ta de salud para tales caminos todavia por lo que toca a la mansion que dichos visitadores hasen 
en Lipes y en otras partes sin pasar al dicho puerto parece es gozar de la combeniencia grande que tienen y revsar el trabajo y e[roto] sierto e estrañado harto lo referido //

\section{[f. 2v]}

en que vuestra magestad se seruira de proueer lo que mas combenga Dios guarde la catholica y red persona de vuestra magestad como la christiandad a menester de esta ciudad de La Plata y marzo 22 de 1684.

Doctor don Juan de la Peña Salacer [rúbrica] 